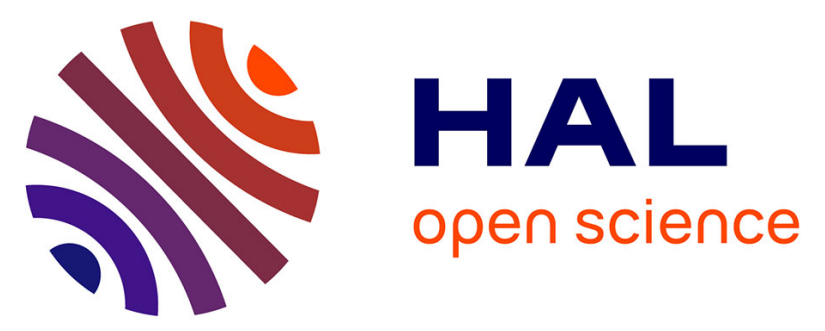

\title{
Plant dispersal traits determine hydrochorous species tolerance to connectivity loss at the landscape scale
}

Lisa Favre-Bac, Barbara Lamberti-Raverot, Sara Puijalon, Aude Ernoult, Francoise Burel, Ludovic Guillard, Cendrine Mony

\section{To cite this version:}

Lisa Favre-Bac, Barbara Lamberti-Raverot, Sara Puijalon, Aude Ernoult, Francoise Burel, et al.. Plant dispersal traits determine hydrochorous species tolerance to connectivity loss at the landscape scale. Journal of Vegetation Science, 2017, 28 (3), pp.605-615. 10.1111/jvs.12518 . hal-01528393

\section{HAL Id: hal-01528393 \\ https://hal-sde.archives-ouvertes.fr/hal-01528393}

Submitted on 4 Jul 2017

HAL is a multi-disciplinary open access archive for the deposit and dissemination of scientific research documents, whether they are published or not. The documents may come from teaching and research institutions in France or abroad, or from public or private research centers.
L'archive ouverte pluridisciplinaire HAL, est destinée au dépôt et à la diffusion de documents scientifiques de niveau recherche, publiés ou non, émanant des établissements d'enseignement et de recherche français ou étrangers, des laboratoires publics ou privés.

\section{(c)(1)}

Distributed under a Creative Commons Attribution| 4.0 International License 
Received Date : 07-May-2016

Revised Date : 03-Jan-2017

Accepted Date : 04-Jan-2017

Article type : Research article

Co-ordinating Editor : Jodi Price

Coordinating editor: Jodi Price

\section{Title}

Plant dispersal traits determine hydrochorous species tolerance to connectivity loss at the landscape scale

\section{Authors}

Lisa FAVRE-BAC ${ }^{1}$, Barbara LAMBERTI-RAVEROT ${ }^{2}$, Sara PUIJALON $^{2}$, Aude ERNOULT $^{1}$, Françoise BUREL ${ }^{1}$, Ludovic GUILLARD ${ }^{2}$ and Cendrine MONY ${ }^{1, *}$

1 UMR CNRS 6553 «Laboratoire Ecosystèmes, Biodiversité, Evolution » ECOBIO, Université Rennes1, Campus de Beaulieu ; F-35042 Rennes, France.

2 UMR CNRS 5023 «Laboratoire d'Ecologie des Hydrosystèmes Naturels et Anthropisés » LEHNA, Université Lyon1, ENTPE, 43 boulevard du 11 novembre 1918; F69622 Villeurbanne, France

\section{(*) Corresponding author}

Cendrine Mony

Phone number: $(+33) 2.23 .23 .64 .79$

E-mail address: cendrine.mony@ univ-rennes1.fr 
Postal address: UMR CNRS 6553 Ecobio, Université Rennes 1

Campus de Beaulieu, 35042 Rennes, France

\begin{abstract}
Aims: Landscape fragmentation exhibits strong negative consequences on biodiversity. In networks of linear elements, connectivity loss results in a decreased length of connected elements and increased potential barriers, directly impacting the ability of plants to disperse. However, species vary in their tolerance to connectivity loss, likely due to differences in dispersal strategies. We investigated whether species tolerance to decreased ditch network connectivity is determined by seed traits. We selected as a case study, water-dispersed plant species in a ditch network.
\end{abstract}

Location: Ditch network established in an intensive agricultural area in northern France.

Methods: We selected 27 sites of 500 x $500 \mathrm{~m}$, where we calculated connectivity indices based on the length of connected ditches, intersection and culvert number. For each parameter, we calculated plant tolerance levels by analysing species changes in occurrence in response to change in connectivity values. Concurrently, we measured in laboratory conditions five seed traits involved in plant movement and establishment in standing aquatic systems and analysed their explanatory power in plant tolerance to fragmentation.

Results: All traits were significantly related to at least one component of ditch network connectivity. We interpreted the following two strategies in plant tolerance to connectivity loss from the results: (1) in networks where the connected network length was short plants displayed short-distance dispersal with less efficient sexual reproduction, probably in favour of local vegetative multiplication; and (2) in networks with a high density of culverts or intersections, plants displayed seeds with reduced local retention, where seeds had the capacity to overcome long and frequent trapping events. In highly branched networks, plants exhibited also higher germination rates, promoting seed establishment when trapped along the banks. Seed capacity to be dispersed by wind at the water surface was only a marginal factor in plant tolerance to fragmentation.

Conclusions: Connectivity loss acted as a filter on species seed traits. The results of our study offer an enhanced understanding of plant dispersal in fragmented standing aquatic networks and emphasise the importance of developing functional approaches in landscape studies.

Keywords: Landscape fragmentation; Seed dispersal; Plant strategies; Aquatic systems; Hydrochory; Plant traits

\title{
Running title
}

Seed traits influence tolerance to fragmentation 


\section{Introduction}

Landscape fragmentation resulting from decreased habitat size and increased isolation of habitat patches is unequivocally recognized as a major driver of biodiversity loss (Debinski \& Holt 2000; Fahrig 2003; Fischer \& Lindenmayer 2007). Connectivity is based on the ability of the different landscape elements to facilitate or impede the movement of individuals through the landscape (Taylor et al. 1993). Reduced connectivity decreases the ability of propagules originating from the regional species pool to reach a specific location (Damschen et al. 2008). These factors might result in strong negative demographic (Brown \& KodricBrown 1977; Dornier \& Cheptou 2012) and deleterious genetic (Richards 2000; Newman \& Tallmon 2001) consequences on populations, impacting plant species persistence and occurrence at the metapopulation level (Jacquemyn et al. 2003; Piessens et al. 2005; Lindborg et al. 2014). Some species are more tolerant to these negative influences, suggesting possible compensation effects due to their dispersal strategies.

Few studies have investigated the role of dispersal strategies in plant resistance to connectivity loss (but see Kolb \& Dieckmann 2005; Lindborg 2007). In the literature available, two main trait types - high number of dispersers and long-distance dispersal - have been shown to be of particular importance. A high number of potential dispersers increases the probability of reaching isolated habitat patches (Eriksson \& Jakobsson 1998) and is determined by a high plant investment in seed production or in the production of dispersible vegetative propagules. Long-distance dispersal additionally enables propagules to reach isolated habitat patches (Johst et al. 2002; Nathan 2006) and is promoted by the selection of particular vector types such as wind or water but also by traits such as seed velocity or buoyancy (Vittoz \& Engler 2007; Nathan et al. 2008). However, in many systems, having a low number of dispersers or a low dispersal distance do not fully explain plant vulnerability to fragmentation, particularly because connectivity includes both the ability for seeds to 
disperse a certain distance and the ability to go over less permeable landscape elements, and/or potential obstacles. More work is needed in characterising dispersal mechanisms to better elucidate how dispersal traits mediate species' response to connectivity loss.

In the present study, we investigated how species respond to connectivity loss focusing on hydrochorous plant species. Connectivity loss can be a major threat to biodiversity in many ecosystems, especially in wetland systems which harbor a large number of species (Gopal et al., 2002). Regulation of river systems as well as drainage for agricultural uses have contributed to important changes in agricultural landscapes (Tockner \& Stanford 2002; Zedler \& Kercher 2005) contributing to the isolation of wetland patches. Hydrochorous dispersal is then of particular importance for population viability because water can facilitate long-distance dispersal events. Such dispersal is likely to be dependent on the aquatic network structure and characteristics (Pollux et al., 2009; Nilsson et al., 2010).

In linear networks, water-dispersal efficiency was at first studied in lotic systems (Nilsson et al., 2010) and depended on water current direction and velocity (Pollux et al. 2009). However, fewer studies on lentic systems have been conducted, where the absence of permanent water movement might substantially change the mechanisms involved in dispersal (Van den Broeck et al. 2005; Van Dijk et al. 2014). In these slow-flowing systems, longdistance dispersal is likely to involve several events of seed-stranding along banks and remobilization following heavy rains and high winds, rather than a single dispersal event (Nilsson et al. 2010). This suggests the importance of dispersal traits favouring seed buoyancy, including low seed density or long floating durations (Nilsson et al. 2002; Carthey et al. 2016), both being related with seed mass (De Ryck et al. 2012; van der Stocken et al. 2015). Floating dispersal capacity depends also on some morphological features of seeds: rounder seeds are for instance less likely to be trapped by vegetation, and therefore expected to disperse more quickly (Chang et al. 2008; Chambert \& James 2009; O’Hare et al. 2011). 
The absence of current might also accentuate the role of wind in seed movement at the water surface (Soomers et al. 2010; Sarneel et al. 2014; Van der Stocken et al. 2013) and select species which seeds have the capacity to move via wind at the water surface (Soomers et al. 2010).

In addition to the physical connection of systems, permeability in these linear networks might be associated with the occurrence of seed trapping factors, such as obstacles or intersections (Levine \& Murrell 2003). Consequently, traits might be filtered that reduce seed retention ability (Schneider \& Sharitz 1988; Johansson \& Nilsson 1993). For instance long and fine seeds are more aligned with flow, being more able to get through man-made obstacles (De Ryck et al. 2012). Tolerance strategy may also involve traits supporting seeds to be trapped over long time (e.g. long buoyancy, Chang et al. 2008), or alternatively establish when seeds are retained at a site. In the latter case, seed germination as well as the internal resource available for germination and establishment (indicated through seed mass) might be involved in plant establishment when seeds are trapped along riverbanks.

Our objectives were to analyse the role of seed traits in hydrochorous plant species tolerance to connectivity loss. This study was performed on a dense ditch network in an intensive agricultural floodplain in northern France. A preliminary study demonstrated the ditch network structure influenced hydrochorous plant community composition at the landscape scale, suggesting the potential role ditches serve as dispersal corridors (Favre-Bac et al. 2014). We measured seed traits from a selection of hydrochorous plant species. We analysed then if species tolerance to ditch network connectivity loss was promoted by particular dispersal traits. We assessed ditch connectivity as the interplay between different components, including connected ditch lengths (i.e. potential dispersal pathways); and presence of factors with potential filtering and trapping effects, such as culverts and intersections. We expected the following selection of traits: 
1) Within long-distance connected ditch networks, species might display traits promoting long-distance dispersal (low seed mass, high buoyancy, and/or efficient dispersal via wind at the water surface).

2) Within networks with culverts or intersections, species might display traits promoting dispersal ability to cross potential barriers or traps (changes in seed morphology or high buoyancy) or facilitate plant establishment when trapped (high germination rates and high seed mass).

\section{Materials and methods}

Study area

The study area comprised $83 \mathrm{~km}^{2}$ located in northern France $\left(50^{\circ} 38^{\prime} 36.72^{\prime}, \mathrm{N}, 2^{\circ} 46^{\prime}\right.$ $28.23 "$ E and $50^{\circ} 32^{\prime} 50.09^{\prime}, \mathrm{N}, 2^{\circ} 35^{\prime} 40.70^{\prime}$ E). The region is a drained floodplain characterized by a flat topography and intensive agricultural practices. A dense ditch network was constructed for water drainage and diversion and covers $642 \mathrm{~km}$ throughout the area (Fig. 1). Twenty-seven $500 \mathrm{~m}$ x $500 \mathrm{~m}$ sampling sites were established to represent variation in network connectivity and analyse species response to connectivity (see Favre-Bac et al. 2014 for site selection details). They were located at least $500 \mathrm{~m}$ apart in order to reduce the impact of spatial autocorrelation.

\section{Assessment of species sensitivity to connectivity loss}

For each $500 \mathrm{~m}$ x $500 \mathrm{~m}$ sampling site, we measured species occurrence and connectivity variables (see below) to examine species tolerance to connectivity loss. Nine ditch banks were selected within each of the 27 sites (for more details, see Favre-Bac et al. 2014), resulting in 243 ditches. For each of the 243 ditches sampled, we recorded species presence along one bank using a $20 \mathrm{~m}$ long plot. From this survey, we selected 17 
hydrochorous species distributed throughout the study area (Table 1). Species were considered as hydrochorous when they were identified as primarily dispersed by water in the LEDA Traitbase (http://www.leda-traitbase.org; Kleyer et al. 2008). For each of the 17 species, we calculated species occurrence at the sampling site level as the number of plots where the species was recorded over the nine surveyed for each site.

For the same 27 sampling sites, we examined three components of ditch connectivity. Measures were computed for each component and each site within simulated catchment areas. The simulated catchment areas were calculated as the sum of measured distance of each ditch connected to each sampling plot within a threshold distance, taking into account flow orientation (Fig. 2). For each threshold distance, we subsequently merged the nine catchment areas surrounding the nine sampled ditch banks to obtain one catchment area for the $500 \mathrm{~m} \times 500 \mathrm{~m}$ sampling site. We used three threshold distances: 100, 300, and $500 \mathrm{~m}$ to cover the range of potential dispersal distances via hydrochory (Soomers et al. 2013). Catchment areas were calculated using the Network Analyst extension for ArcGIS 10.0 (ESRI, Redlands, CA). This tool allowed us to implement flow directions with one-way and two-way orientations in the network dataset. We calculated three connectivity variables for each catchment (range and median values described in Table 1):

1) Catchment total connected ditch length. The value provides a distance estimate of ditches potentially available for dispersal and therefore, potential dispersal pathways. It was measured as total connected ditch length.

2) The number of culverts. Culverts might represent partial hydrochorous seed dispersal barriers (Soomers et al. 2010). Culverts were mapped based on aerial photographs and we validated these records in the field.

3) The number of ditch intersections. Ditch intersections can be viewed as indicators of 
propagule traps in stagnant waters within the ditch network (Favre-Bac et al. 2014). We identified all intersections within the catchment areas that connected three ditch segments or more.

Individual species tolerance to ditch network connectivity loss was quantified using Canonical Correspondence Analysis (CCA, Ter Braak 1987). We undertook a separate analysis for every scale and connectivity variable combination (nine analyses in total). We coupled the matrix of species occurrence under the constraint of the matrix of fragmentation measures per sampling site (Fig. 3). The matrix of species occurrence includes the number of species occurrences within each sampling site calculated as the sum of occurrences over the nine plots. Significance was established using Monte-Carlo permutation tests. Species scores along the CCA axes were subsequently considered as a response estimator to connectivity loss (we will refer to this as a tolerance index). Tolerance indices were expressed along a fragmentation gradient for all indices; higher values indicated species preferential occurrence in fragmented networks, whereas lower values indicated species preferential occurrence in non-fragmented networks (long-connected ditches, low number of culverts or low number of intersections).

\section{Measurement of plant dispersal traits}

We assessed only seed dispersal traits, as a propagule trap study revealed substantial seed dominance over vegetative fragments in the propagules dispersed in the ditches (unpublished data). Seeds were collected from July to September 2013 depending on the species. They were collected from ten different locations distributed throughout the study area. When possible, ten individuals from each species were sampled from each location (Table 3). They were collected as spatially distributed along the $20 \mathrm{~m}$-plot so as to limit the probability of 
sampling the same individuals, which can be possible for clonal plant species.

Sampled seeds were further air-dried and stored at $4{ }^{\circ} \mathrm{C}$ before trait measurements, which were done in February 2014. We measured under laboratory conditions the following five seed traits which are likely to impact water-dispersal in slow-flowing water:

1) Seed mass. Bundles of ten seeds per species were oven dried and weighed $\pm 0.0001 \mathrm{~g}$ (Perez-Harguindeguy et al. 2013).

2) Seed buoyancy. Two groups of 50 seeds of each species were placed on rectangular plastic trays filled with water (100 seeds in total). Each tray was equipped with a tapped plastic tube distributed along the entire interior wall of the tray and linked to a compressor blowing air through the tubes' holes (Fig. 4A). This served to reduce surface tension that might artificially elevate the observed seed's floating capacity and gently stir the water. The number of floating and sunk seeds were counted after 5 min and $6 \mathrm{hr}$ on day 1; followed by once per day for wk 1; and twice per wk for the following 5 wks. This protocol allowed us to determine the time after which $50 \%$ of the seeds had sunk $\left(\mathrm{t}_{50}\right)$. For species where seeds had not reached the $50 \%$ threshold by the end of the experiment, values were subsequently set to a maximum time, i.e. $43 \mathrm{~d}$.

3) Seed morphology. We measured the projected coefficient form on scanned seeds using WinSEEDLE (Regent instruments Inc.). This trait estimated seed roundness: values close to 0 and 1 indicate long and round seeds respectively.

4) Seed velocity under constant wind. We designed a system under constant wind conditions to quantify seed movement, which was estimated as seed velocity at water surface under given wind conditions. For this purpose, we used a flume ( $\mathrm{L} 8 \times \mathrm{W} 0.2 \times \mathrm{H} 0.3 \mathrm{~m})$ filled with $10 \mathrm{~cm}$ of water (Fig. 4B). At one end of the channel, an air blower was connected to generate a wind layer over the water surface, followed by a honeycomb structure to reduce 
turbulence; the other end was sealed. The top of the section of the flume was sealed with plates except at the upper section of the downwind-end, which created an open wind tunnel. Vertical plates were placed in the water to prevent formation of water current. Wind speed was measured with an ultrasonic wind sensor (CV7-V, LCJ Capteurs, France) and measurements were obtained using an average $6.6 \mathrm{~km} \cdot \mathrm{h}^{-1}$ wind speed. The test section was the $80 \mathrm{~cm}$ central part of the flume, where simulated wind flow was most stable. A small plastic tube was inserted vertically into the top of the flume upwind of the measurement zone. The tube was used to release seeds directly at the water surface, and designed so the process was replicable. Seeds were released to the water surface and seed displacement time was manually recorded every $10 \mathrm{~cm}$. We calculated seed dispersal velocity using a regression between distance and the estimated time necessary for the seed to cover a distance of $80 \mathrm{~cm}$ (termed dispersal velocity under wind (in $\left.\mathrm{m}_{\mathrm{s}} \mathrm{s}^{-1}\right)$ ). Two buoyant polystyrene spheres were used as controls and regularly timed before, between, and after each species seeds measurements. One species (Calystegia sepium) was excluded from the dataset for this trait measurement, due to experimentation problems.

5) Seed germination. For each species, we sowed two groups of 50 seeds in two separated plastic trays filled with potting soil and covered with a thin sand layer (100 seeds in total). Species were sown in independent trays. The trays were maintained under greenhouse conditions and watered daily. We surveyed emergence rates for 17 wks from June to October 2014, and seedlings were removed following definitive species identification. Emergence rates were considered as indicating seed germination rates and was calculated as a percentage of germination. 


\section{Statistical analyses}

In order to check for potential redundancy or existing trade-offs between traits, we tested the degree of correlations between seed traits using Pearson's correlation analysis. We performed linear regression analyses between the tolerance index (per type of connectivity variable and catchment size) obtained through CCA scores as the independent variable and the five measured dispersal traits taken individually as the dependent variable. Residuals of all models were normally distributed, with the exception of seed mass. Therefore, nonparametric Spearman tests were used to test the correlations between seed mass and fragmentation index. All statistical analyses were conducted using R 3.1.1 (R Core Team 2014).

\section{Results}

CCA Analyses were significant for six of nine connectivity variables, with a marginal significance for the number of intersections and connected ditch lengths calculated within the $500 \mathrm{~m}$ catchment areas to influence plant species occurrence (Table 2). Only culvert number within the $100 \mathrm{~m}$ catchment area exhibited no influence on plant species occurrence.

A large range of variation between species was exhibited in all measured traits (Table 3). Seed mass varied from light seeds in Lycopus europaeus $(\mu=0.0002 \mathrm{~g})$ to heavy in Iris pseudoacorus $(\mu=0.0437 \mathrm{~g})$. Projected coefficients varied from round (Brassica nigra; Galium palustre) to long and thin (Glyceria maxima; Sparganium erectum) seeds. Buoyancy was the most variable trait, characterized by poorly floating seeds in B. nigra and Trifolium pratensis $\left(\mathrm{t}_{50}=0.04 \mathrm{~d}\right)$ to long-term buoyancy in Rumex cripsus, S. erectum, and $I$. pseudoacorus $\left(\mathrm{t}_{50}>43 \mathrm{~d}\right)$. Dispersal under wind conditions exhibited reduced variability among species from $0.06 \mathrm{~m} . \mathrm{s}^{-1}$ in L. europeaeus to $0.33 \mathrm{~m} . \mathrm{s}^{-1}$ in I. pseudoacorus. 
Germination rates varied from $100 \%$ for $R$. crispus to less than $10 \%$ in a species group comprising Lamium album, L. europaeus, Carex riparia, Mercurialis annua, Calystegia sepium, and S. erectum. Seed traits were not significantly correlated, with the exception of seed mass and buoyancy $t_{50}$, which were significantly positively correlated $(r=0.67, P<$ 0.01; Pearson's Correlation test) and seed mass and dispersal velocity under wind conditions $(r=0.51, P<0.05 ;$ Pearson's Correlation test $)$.

All traits were significantly related to one or several indices of tolerance to connectivity loss (Table 4). These relationships were additionally dependent on catchment size. Species with more frequent occurrences in networks with short connected ditch distances exhibited lower seed mass (significant for $100 \mathrm{~m}$ catchment size and marginally significant for 300 and $500 \mathrm{~m}$ catchment sizes) and rounder seeds (significant for $300 \mathrm{~m}$ catchment size and marginally significant for 100 and $500 \mathrm{~m}$ catchment sizes). They also displayed lower germination rate (significant for 100 and $300 \mathrm{~m}$ catchment sizes and marginally significant for $500 \mathrm{~m}$ catchment size) and decreased dispersal via wind at the water surface capacity (marginally significant for 100 and $300 \mathrm{~m}$ catchment sizes) compared with species occurring in connected networks. Species distributed preferentially in networks with high culvert numbers displayed significantly longer and thinner seeds and increased buoyancy time (significant for all catchment sizes for both traits) than for species occurring in more permeable networks. Species distributed in networks with high intersection numbers displayed responses similar to those observed in networks with high culvert numbers in terms of seed mass (significant for $300 \mathrm{~m}$ but marginally significant for 100 and $500 \mathrm{~m}$ catchment sizes) and form (significant for $100 \mathrm{~m}$ catchment size) compared with species in networks with a high number of culverts. Additionally, species displayed increased seed germination rate (significant for all catchment sizes) and increased wind dispersal capacity at the water surface (marginally significant for 100 catchment size) compared with species occurring in 
less branched networks. Dispersal velocity under wind conditions was only selected at the tendency level $(\mathrm{p}<0.1)$, indicating low involvement of this trait in plant adaptation to connectivity loss whatever the type of tolerance indice considered.

\section{Discussion}

Scale-dependent species landscape distribution to connectivity reduction

We found connectivity loss in water-dispersed plant species was characterized by: 1) decreased potential dispersal pathways (i.e. connected ditch lengths); and 2) decreased network permeability due to potential barriers (culvert number) and retention events (intersection number). These two components appeared as significant drivers of species assemblages at the landscape scale.

Connectivity loss acted on plant distribution at different landscape scales depending on the components considered. Decreased connected ditch length and increased intersection number impacted plant distribution at short and intermediate distances $(\leq 300 \mathrm{~m})$ but culvert number at increased distances $(\geq 300 \mathrm{~m})$. Decreased physical ditch connectivity was a major determinant of plant distribution, confirming that water was the main dispersal vector of these plants. Our results suggested water-dispersal had a higher chance of success at distances shorter or equal to $300 \mathrm{~m}$. Dispersal distance is generally best modelled as a curve/kernel, with the highest frequency for short distances and rare long-distance dispersal events (Nathan et al. 2008). This curve is difficult to generate under natural conditions and therefore estimates are often based on modelling studies (Cain et al. 2000) or experimental evaluation in channels (Boedeltje et al. 2003; Riis \& Sand-Jensen 2006). Soomers et al. (2010) studied dispersal of three wetland plant species within a Dutch ditch network and reported mean dispersal distances ranged from 34 to 451 meters, congruent with our results. 
Intersection number influenced network permeability by acting primarily at shorter scales than culvert number. Both parameters varied within each scale, ensuring the effects were not the result of reduced variation at one of the three catchment areas. Subsequently, this result suggested the branching network structure might be a more effective plant dispersal barrier in these standing water systems compared with culverts. This might be linked to the necessary change in seed dispersal orientation when the ditches intersect in contrast to culverts that are placed in the course of the ditch. This change in seed trajectory may be difficult in stagnant ditches or with low current velocity.

\section{Ditch network connectivity components select different dispersal traits}

All studied seed traits responded to at least one connectivity component, but different dispersal strategies were selected depending on the tolerance indices evaluated. Decreased connected ditch distances appear to favour species with round seeds, lower seed mass and reduced movement under wind conditions. Furthermore, these seeds displayed lower germination rates. The lack of a relationship between seed mass and germination rate suggested the independence of seed germination and establishment on the level of internal seed resources as already demonstrated by Shipley and Parent (1991) in wetland species. Low seed mass, reduced movement under wind conditions and low germination together indicated the potential selection in networks of species exhibiting smaller investments in sexual reproduction, in favour of vegetative multiplication. This strategy would be beneficial in short ditch networks where long-distance dispersal is highly restricted or even suppressed, while vegetative dispersal ensures more efficient local dispersal and population persistence (Stocklin \& Winkler 2004; Pluess \& Stocklin 2005). 
We showed decreased network permeability through potential barriers and retention events promoted some degree of similarity between the functional responses selected. Networks with a high number of culverts appear to favour species with long and less round seeds and a higher buoyancy. Seeds with such morphology may better pass the culverts sections: this shape corresponds to a streamlined morphology that can lead to the seeds being aligned to flow direction, which would help the seeds to pass through obstacles (De Ryck et al. 2012). Additionally, culverts or intersections increase the role of changes in wind direction or water levels in seed remobilization. Seeds with increased buoyancy, which tolerate a high number of retention events, are likely selected under these conditions. Networks with high intersection number favour species with high seed mass and seed germination rates, whereas these traits are independent of culvert number. This strategy may favour plant establishment when seeds are trapped in these intersections

Dispersal traits as response traits to connectivity-driven dispersal filters in fragmented landscapes

We demonstrated that hydrochorous plant tolerance to connectivity loss was promoted by species seed traits. Following Lavorel et al. (1997), these seed traits may be considered as response traits to connectivity loss. In contrast to most local filters, connectivity was shown as a complex landscape parameter, with several components independently impacting dispersal response traits. For most traits, loss in structural connectivity displayed an opposite effect compared with loss in network permeability. In reduced permeability networks, seed traits increasing a species capacity to tolerate frequent retention-remobilization processes (e.g. high buoyancy) were particularly influential in these slow-flowing or stagnant systems. The results of our study served to understand and predict the effects of connectivity loss on hydrochorous plant spatial distribution at the landscape scale. To our knowledge, this 
research is one of very few that examines functional approaches at the metapopulation scale.

Next step would be to take into account the potential effects of intraspecific variability (Albert et al., 2010; Jung et al., 2010; Violle et al., 2012) in plant individual response to the fragmentation.

\section{Acknowledgements}

The authors are grateful to Félix Vallier, who assisted with the experimental design, and Vanessa Gardette, Coralie Avoscan, Youssouf Sy, and Anaïse Poisson, who contributed to trait measurements. This work was funded by a grant from the FRB-Nord Pas de Calais region (CORECOL project).

\section{References}

Albert, C., Thuiller, W., Yoccoz, N., Soudant, A., Boucher, F., Saccone, P. \& Lavorel, S. 2010. Intraspecific functional variability: extent, structure and sources of variation. Journal of Ecology 98: 604-613.

Boedeltje, G., Bakker, JP., Bekker, RM., Van Groenendael, JM. \& Soesbergen, M. 2003. Plant dispersal in a lowland stream in relation to occurrence and three specific lifehistory traits of the species in the species pool. Journal of Ecology 91: 855-866.

Brown, JH. \& Kodric-Brown, A. 1977. Turnover rates in insular biogeography: effects of immigration on extinction. Ecology 58: 445-449.

Cain, M., Milligan, B. \& Strand, A., 2000. Long-distance seed dispersal in plant populations. American Journal of Botany 87: 1217-1227.

Carthey, A. J., Fryirs, K. A., Ralph, T. J., Bu, H., \& Leishman, M. R. 2016. How seed traits predict floating times: a biophysical process model for hydrochorous seed transport behaviour in fluvial systems. Freshwater Biology 61: 19-31.

Chambert, S. \& James, CS. 2009. Sorting of Seeds by Hydrochory. River Research and Applications 61: 48-61.

Chang, ER., Veeneklaas, RM., Buitenwerf, R., Bakker, JP. \& Bouma, TJ. 2008. To move or not to move: determinants of seed retention in a tidal marsh. Functional Ecology 22: $720-727$.

Damschen, E.I., Brudvig, L.A., Haddad, N.M., Levey, D.J., Orrock, J.L. \& Tewksbury, J.J. 2008. The movement ecology and dynamics of plant communities in fragmented landscapes. Proceedings of the National Academy of Sciences of the United States of America 105: 19078-19083.

De Ryck, D. J., Robert, E. M., Schmitz, N., Van der Stocken, T., Di Nitto, D., DahdouhGuebas, F., \& Koedam, N. 2012. Size does matter, but not only size: Two alternative 
dispersal strategies for viviparous mangrove propagules. Aquatic Botany 103: 66-73.

Debinski, D.M. \& Holt, R.D. 2000. A survey and overview of habitat fragmentation experiments. Conservation Biology 14: 342-355.

Dornier, A. \& Cheptou, P-O. 2012. Determinants of extinction in fragmented plant populations: Crepis sancta (Asteraceae) in urban environments. Oecologia 169: 70312.

Eriksson, O. \& Jakobsson, A. 1998. Abundance, distribution and life histories of grassland plants: a comparative study of 81 species. Journal of Ecology 86: 922-933.

Fahrig, L. 2003. Effects of Habitat Fragmentation on Biodiversity. Annual Review of Ecology, Evolution, and Systematics 34: 487-515.

Favre-Bac, L., Ernoult, A., Mony, C., Rantier, Y., Nabucet, J. \& Burel, F. 2014. Connectivity and propagule sources composition drive ditch plant metacommunity structure. Acta Oecologica 61: 57-64.

Fischer, J. \& Lindenmayer, D.B. 2007. Landscape modification and habitat fragmentation : a synthesis. Global Ecology and Biogeography 16: 265-280.

Gopal, B., Junk, W.J. \& Davis, J.A. (Eds.) 2002. Biodiversity in Wetlands: Assessment, Function and Conservation. Volume 2. Leiden, The Netherlands: Backhuys Publisher.

Jacquemyn, H., Butaye, J. \& Hermy, M. 2003. Impacts of restored patch density and distance from natural forests on colonization success. Restoration Ecology 11: 417-423.

Johannsson, M.E. \& Nilsson, C. 1993. Hydrochory, population dynamics and distribution of the clonal aquatic plant Ranunculus lingua. Journal of Ecology 81: 81-91.

Johst, K., Brandl, R. \& Eber, S. 2002. Metapopulation persistence in dynamic landscapes: the role of dispersal distance. Oikos 98: 263-270.

Jung, V., Violle, C., Mondy, C., Hoffmann, L. \& Muller, S. 2010. Intraspecific variability and trait-based community assembly. Journal of Ecology 98: 1134-1140.

Kleyer, M., Bekker, R.M., Knevel, I.C. et al. 2008. The LEDA Traitbase : a database of lifehistory traits of the Northwest European flora. Journal of Ecology 96: 1266-1274.

Kolb, A. \& Dieckmann, M. 2005. Effects of life-history traits on responses of plant species to forest fragmentation. Conservation Biology 19: 929-938

Lavorel, S., McIntyre, S., Landsberg, J. \& Forbes, T.D. 1997. Plant functional classifications: From general groups to specific groups based on response to disturbance. Trends in Ecology and Evolution 12: 474-478.

Levine, J.M. \& Murell, D.J. 2003. The Community-level consequences of seed dispersal patterns. Annual Review of Ecology, Evolution, and Systematics 34: 549-574.

Lindborg, R. 2007. Evaluating the distribution of plant life-history traits in relation to current and historical landscape configurations. Journal of Ecology 95: 555-564.

Lindborg, R., Plue, J., Andersson, K. \& Cousins, S.A.O. 2014. Function of small habitat elements for enhancing plant diversity in different agricultural landscapes. Biological Conservation 169: 206-213.

Nathan, R. 2006. Long-Distance dispersal of plants. Science 313: 786-788.

Nathan, R., Schurr, F.M., Spiegel, O., Steinitz, O., Trakhtenbrot, A. \& Tsoar, A. 2008. Mechanisms of long-distance seed dispersal. Trends in Ecology \& Evolution 23: 638647.

Newman, D. \& Tallmon, D.A. 2001. Experimental evidence for beneficial fitness effects of gene flow in recently isolated populations. Conservation Biology 15: 1054-1063.

Nillsson, C., Andersson, E., Merritt, D. \& Johansson, M.E. 2002. Differences in riparian flora between riverbanks and river lakeshores explained by dispersal traits. Ecology 83: 2878-2887.

Nilsson, C., Brown, R.L., Jansson, R. \& Merritt, D.M. 2010. The role of hydrochory in 
structuring riparian and wetland vegetation. Biological Reviews of the Cambridge Philosophical Society 85: 837-858.

O’Hare, J.M., O’Hare, M.T., Gurnell, A.M., Scarlett, P.M., Liffen, T. \& McDonald, C. 2011. Influence of an ecosystem engineer, the emergent macrophyte Sparganium erectum, on seed trapping in lowland rivers and consequences for landform colonisation. Freshwater Biology 57: 104-115.

Piessens, K., Honnay, O. \& Hermy, M. 2005. The role of fragment area and isolation in the conservation of heathland species. Biological Conservation 122: 61-69.

Pluess, A.R. \& Stocklin, J. 2005. The importance of population origin and environment on clonal and sexual reproduction in the alpine plant Geum reptans. Functional Ecology 19: 228-237.

Pollux, B.J.A., Luteijn, A., van Groenendael, J.M. \& Ouborg, N.J. 2009. Gene flow and genetic structure of the aquatic macrophyte Sparganium emersum in a linear unidirectional river. Freshwater Biology 54: 64-76.

Richards, C.M. 2000. Inbreeding depression and genetic rescue in a plant metapopulation. The American Naturalist 155: 383-394.

Riis T. \& Sand-Jensen, K., 2006. Dispersal of plant fragments in small streams. Freshwater Biology 51: 274-286.

Sarneel, J.M., Beltman, B., Buijze, A., Groen, R. \& Soons, M.B. 2014. The role of wind in the dispersal of floating seeds in slow-flowing or stagnant water bodies. Journal of Vegetation Science 25: 262-274.

Schneider, R.L. \& Sharitz, R.R., 1988. Hydrochory and regeneration in a bald cypress-water tupelo swamp forest. Ecology 69: 1055-1063.

Shipley, B. \& Parent, M. 1991. Germination responses of 64 wetland species in relation to seed size, minimum time to reproduction and seedling relative growth rate. Functional Ecology 5:111-118.

Soomers, H., Winkel, D.N., Du, Y. \& Wassen, M.J. 2010. The dispersal and deposition of hydrochorous plant seeds in drainage ditches. Freshwater Biology 55: 2032-2046.

Soomers, H., Karssenberg, D., Verhoeven, J.T.A., Verweij, P.A. \& Wassen, M.J. 2013. The effect of habitat fragmentation and abiotic factors on fen plant occurrence. Biodiversity and Conservation 22: 405-424.

Stocklin, J. \& Winkler, E. 2004. Optimum reproduction and dispersal strategies of a clonal plant in a metapopulation: a simulation study with Hieracium pilosella. Evolutionary Ecology 18:563-584.

Taylor, P.D., Fahrig, L., Henein, K. \& Merriam, G. 1993. Connectivity is a vital element of landscape structure. Oikos 68: 571-573.

Ter Braak, C.J.F. 1987. The analysis of vegetation-environment relationship by canonical correspondence analysis. Vegetatio 69: 69-77.

Van Den Broek, T., Van Diggelen, R. \& Bobbink, R. 2005. Variation in seed buoyancy of species in wetland ecosystems with different flooding dynamics. Journal of Vegetation Science 16: 579-586.

Van der Stocken, T., De Ryck, D.J.R., Balke, T., Bouma, T.J., Dahdouh-Guebas, F. \& Koedam, N. 2013. The role of wind in hydrochorous mangrove propagule dispersal. Biogeosciences Discussions 10: 895-925.

Van der Stocken, T., Vanschoenwinkel, B., De Ryck, D. J., Bouma, T. J., Dahdouh-Guebas, F., \& Koedam, N. 2015. Interaction between Water and Wind as a Driver of Passive Dispersal in Mangroves. PloS One 10: e0121593.

Van Dijk, W.F.A., van Ruijven, J., Berendse, F. \& de Snoo, G.R. 2014. The effectiveness of ditch banks as dispersal corridor for plants in agricultural landscapes depends on species' dispersal traits. Biological Conservation 171: 91-98. 
Vittoz, P. \& Engler, R. 2007. Seed dispersal distances: a typology based on dispersal modes and plant traits. Botanica Helvetica 117: 109-124.

Violle, C., Enquist, B.J., McGill, B.J., Jiang, L., Albert, C.H., Hulshof, C., Jung, V. \& Messier, J. 2012. The return of the variance: Intraspecific variability in community ecology. Trends in Ecology and Evolution 27: 244-252.

\section{Tables and figures}

Fig. 1. Study area map, located in Nord - Pas de Calais, northern France. White squares depict the 500x500m sampling sites where plant species tolerance to connectivity loss was assessed.

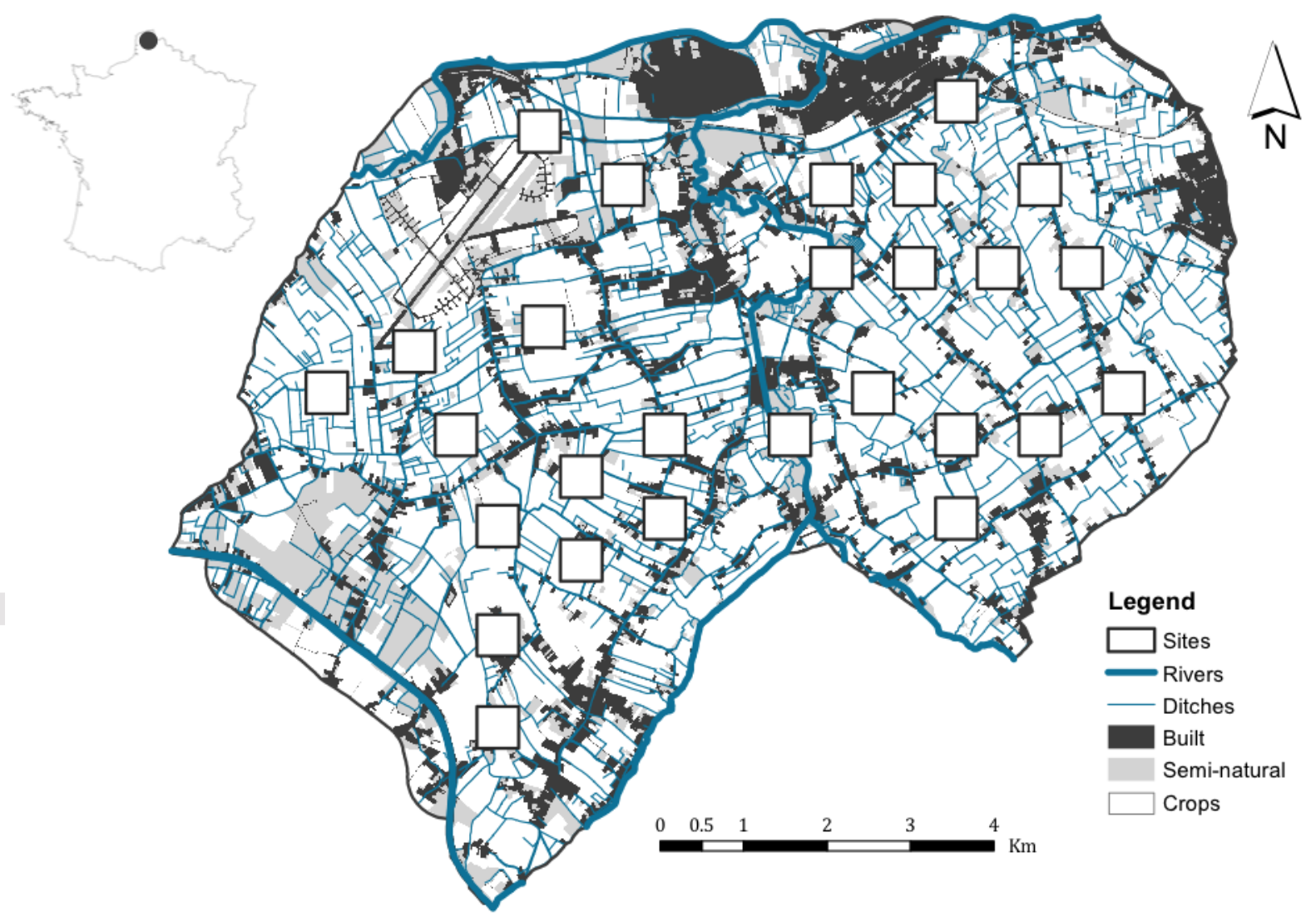


Fig. 2. Three different catchment area scales calculated for a single 500x500m sampling site. Locations of the nine sampling localities within each sampling site are indicated by black dots. Light gray, dark gray and black lines represent the connected ditch distances included in catchment areas around the sampling locations within respectively each threshold distance.

A. $100 \mathrm{~m}$ catchment area; B. $300 \mathrm{~m}$ catchment area; C. $500 \mathrm{~m}$ catchment area.
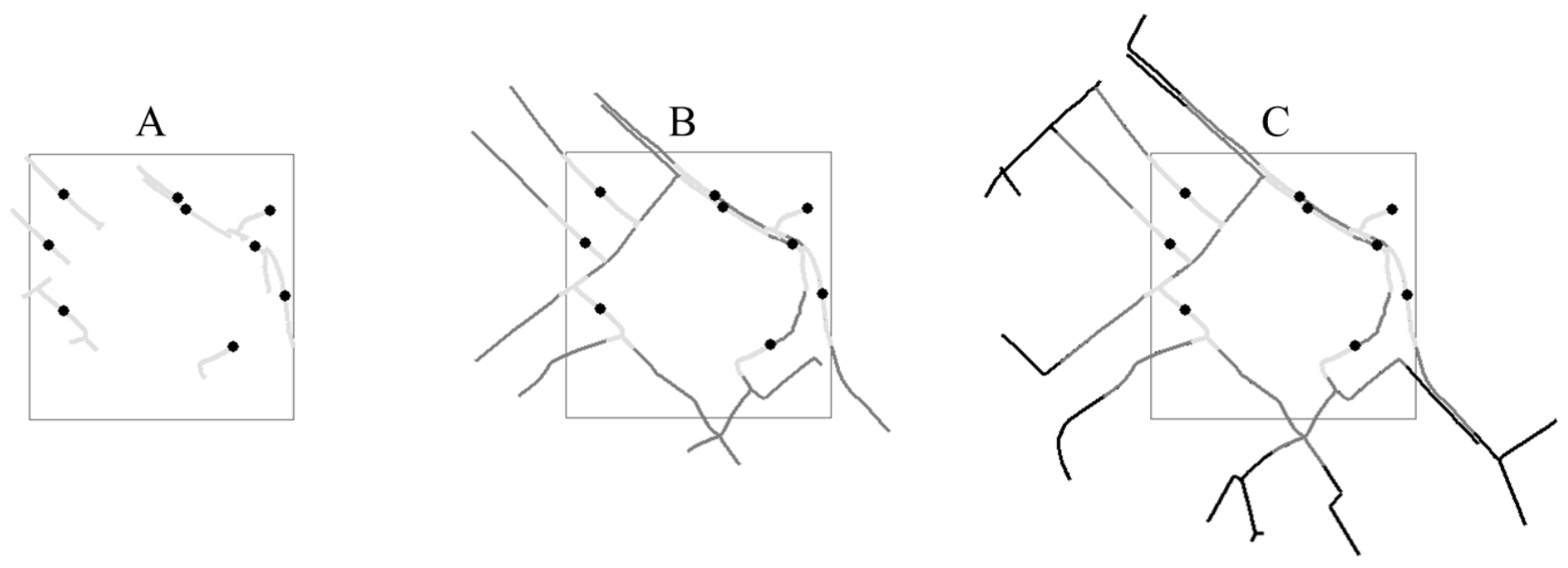
Fig. 3. Plant species response to connectivity loss calculation method. A) connectivity matrix at the landscape site level; B) species occurence matrix at the landscape site level; C) Canonical Correspondance Analysis (CCA) plot; D) plant species response to connectivity loss matrix. $\mathrm{S}_{1}, \mathrm{~S}_{2}, \ldots \mathrm{S}_{\mathrm{p}}$ represent landscape square sites. $\mathrm{V}_{1}$ is the variable of connectivity loss considered; it changes depending on the combination of catchment scale and connectivity component; $\mathrm{Sp}_{1}, \mathrm{Sp}_{2}, \ldots \mathrm{Sp}_{\mathrm{n}}$ are species; $\mathrm{a}_{1}, \mathrm{a}_{2}, \ldots \mathrm{a}_{\mathrm{n}}$ species coordinates on the CCA first axis; R: response to connectivity loss.

Connectivity matrix

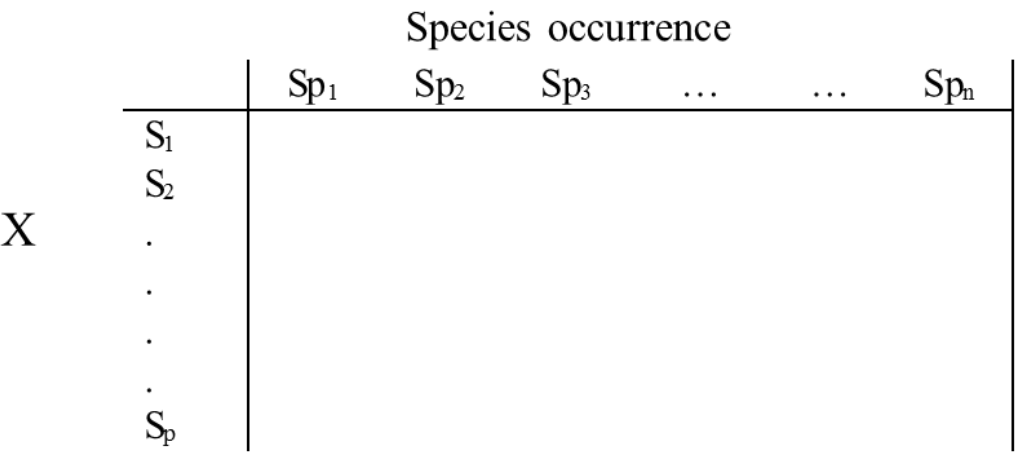

\begin{tabular}{l|l|} 
& $\mathrm{V}_{1}$ \\
\hline $\mathrm{S}_{1}$ & \\
$\mathrm{~S}_{2}$ & \\
$\cdot$ & \\
$\cdot$ & \\
$\cdot$ & \\
. & \\
$\mathrm{S}_{\mathrm{p}}$ &
\end{tabular}

A
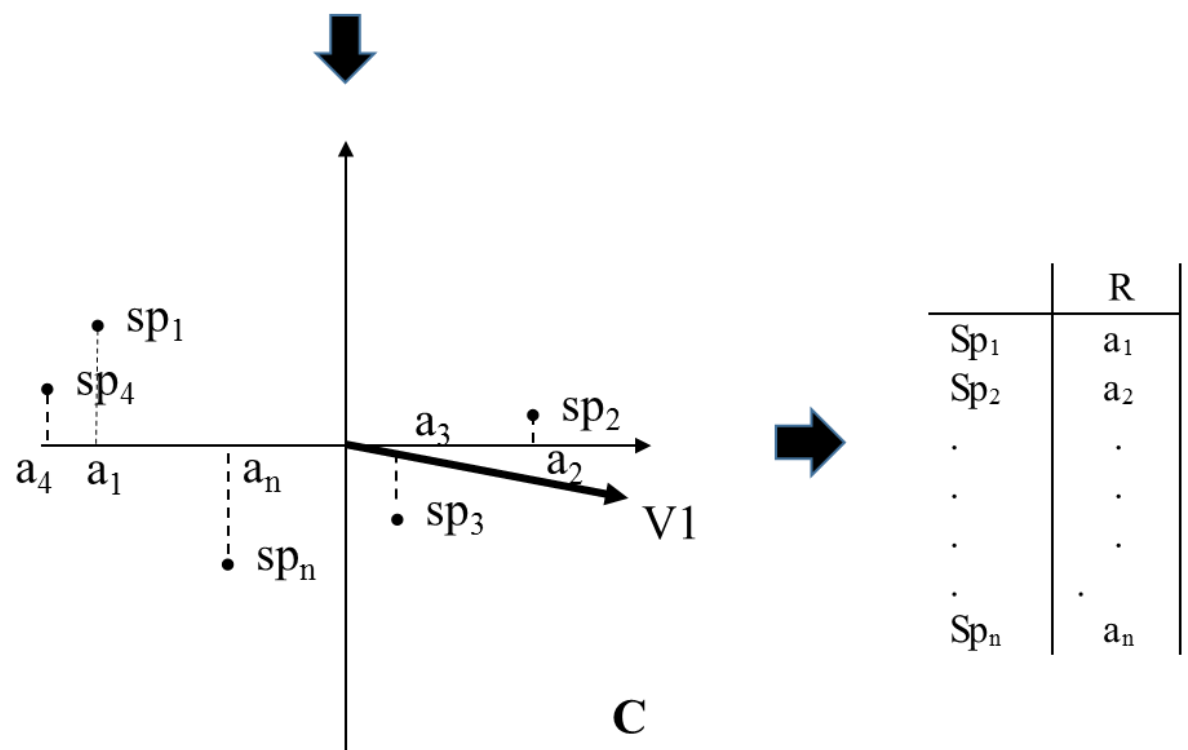

C

D 
Fig. 4. Seed trait measurements under laboratory conditions. A. Seed buoyancy measurement. B. Flume experiment used to measure seed velocity under constant wind.

A

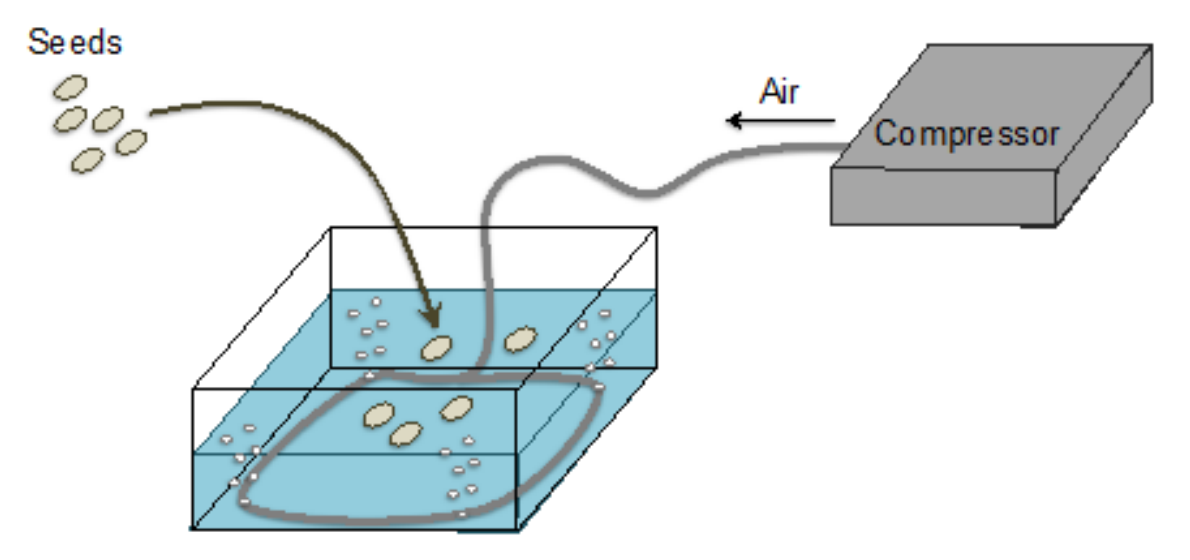

B

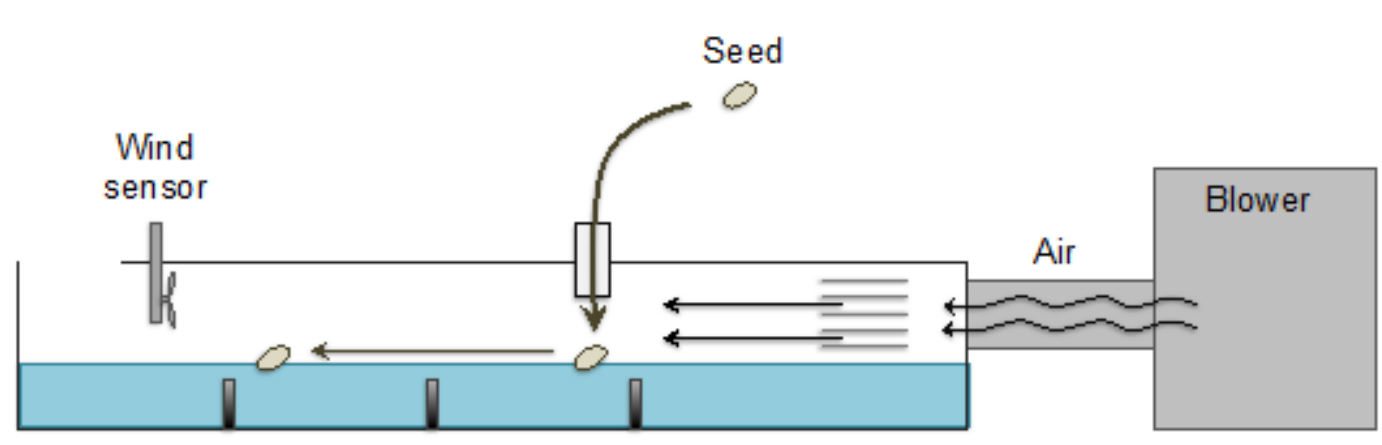


Table 1. List of the seventeen sampled species, number of sampled populations and average trait values measured.

Species

$\begin{array}{ccccc}\begin{array}{c}\text { No } \\ \text { populations }\end{array} & \begin{array}{c}\text { Seed mass } \\ (\mathrm{g})\end{array} & \begin{array}{c}\text { Projected } \\ \text { form coef. }\end{array} & \begin{array}{c}\mathrm{t}_{50} \\ \text { (days) }\end{array} & \begin{array}{c}\text { Dispersal } \\ \text { velocity } \\ \text { under } \\ \end{array} \\ & & & & \text { wind }(\mathrm{m} / \mathrm{s})\end{array}$

\begin{tabular}{lcccccc}
\hline Brassica nigra & 10 & 0.0014 & 0.90 & 0.04 & 0.13 & 16 \\
Calystegia sepium & 10 & 0.0288 & 0.77 & 43 & - & 8 \\
Carex riparia & 10 & 0.0017 & 0.52 & 43 & 0.15 & 6 \\
Filipendula ulmaria & 9 & 0.0005 & 0.54 & 6.54 & 0.12 & 10 \\
Galium palustre & 10 & 0.0025 & 0.88 & 0.18 & 0.11 & 66 \\
Glyceria maxima & 10 & 0.0013 & 0.19 & 2.39 & 0.17 & 26 \\
Iris pseudacorus & 10 & 0.0437 & 0.51 & 43 & 0.33 & 46 \\
Lamium album & 10 & 0.0011 & 0.49 & 0.65 & 0.12 & 4 \\
Lycopus europaeus & 10 & 0.0002 & 0.69 & 20.55 & 0.06 & 6 \\
Mercurialis annua & 10 & 0.0020 & 0.82 & 0.29 & 0.16 & 8 \\
Oenanthe aquatica & 7 & 0.0022 & 0.41 & 7.28 & 0.07 & 58 \\
Phalaris arundinacea & 10 & 0.0004 & 0.37 & 3.34 & 0.06 & 14 \\
Ranunculus repens & 10 & 0.0026 & 0.50 & 1.46 & 0.13 & 56 \\
Rumex crispus & 10 & 0.0036 & 0.31 & 43 & 0.18 & 100 \\
Sparganium erectum & 9 & 0.0231 & 0.26 & 43 & 0.17 & 8 \\
Trifolium pratensis & 10 & 0.0022 & 0.83 & 0.04 & 0.09 & 10 \\
Urtica dioica & 10 & 0.0002 & 0.62 & 1.41 & 0.20 & 18 \\
\hline
\end{tabular}


Table 2. Minimum, maximum and median values for the three connectivity indices (Total connected ditch length, culvert and intersection numbers). They are calculated at the landscape site level for the three-catchment sizes (100, 300 and 500m).

\begin{tabular}{lcccccc}
\hline & \multicolumn{9}{c}{ Scale (m) } \\
\cline { 2 - 7 } Range of variation & Min-Max & Median & Min-Max & Median & Min-Max & Median \\
\hline Total connected & $1120.2-$ & 1581.0 & $3239.6-$ & 5702.9 & $4967.3-$ & 9720.0 \\
ditch length (m) & 2227.2 & & 9388.8 & & 19794.7 & \\
No. of Culverts & $4-21$ & 10 & $8-51$ & 24 & $16-90$ & 36 \\
No. of Intersections & $1-7$ & 3 & $3-17$ & 6 & $3-23$ & 8 \\
\hline
\end{tabular}

Table 3. Percentages of explained deviance from Monte-Carlo randomization tests performed on Canonical Correspondance Analysis (CCA) results for each connectivity variable and catchment sizes $(100,300$ and $500 \mathrm{~m})$. Significance is indicated into brackets. ns. = non significant; $\mathrm{t}=\mathrm{P}<0.1 ; *=\mathrm{P}<0.05 ; * *=\mathrm{P}<0.01 ; * * *=\mathrm{P}<0.001$.

\begin{tabular}{lccc}
\hline & Connected ditch length & No. culverts & No. intersections \\
\hline 100 meters & $9.4(*)$ & $4.8(\mathrm{~ns})$ & $7.8\left(^{*}\right)$ \\
300 meters & $9.5(*)$ & $10.1\left(^{*}\right)$ & $7.8(*)$ \\
500 meters & $7.0(\mathrm{t})$ & $11.1(*)$ & $7.2(\mathrm{t})$ \\
\hline
\end{tabular}


Table 4. Statistical model results for five seed traits (seed mass, projected form coefficient, $\mathrm{t}_{50}$, dispersal velocity under wind, seed germination) and three connectivity variables calculated for 100, 300 and $500 \mathrm{~m}$ catchment sizes. Linear regressions were conducted for all traits with the exception of seed mass. For seed mass, a non-parametric Spearman Correlation Coefficient test was used. Only significant and marginally significant (in italics) results were reported.

\begin{tabular}{|c|c|c|c|c|c|c|c|c|c|c|c|c|c|c|}
\hline & \multicolumn{2}{|c|}{ Seed mass } & \multicolumn{3}{|c|}{ Projected Coef. form } & \multicolumn{3}{|c|}{$\mathrm{t}_{50}$} & \multicolumn{3}{|c|}{$\begin{array}{l}\text { Dispersal velocity } \\
\text { under wind }\end{array}$} & \multicolumn{3}{|c|}{ Seed germination } \\
\hline & $\mathrm{R}$ & $\mathrm{p}$ & Slope & $\mathrm{R}^{2}$ & $\mathrm{p}$ & Slope & $\mathrm{R}^{2}$ & $\mathrm{p}$ & Slope & $\mathrm{R}^{2}$ & $\mathrm{p}$ & Slope & $\mathrm{R}^{2}$ & $\mathrm{p}$ \\
\hline \multicolumn{15}{|c|}{$\begin{array}{l}\text { 1-Decrease in connected } \\
\text { ditch length }\end{array}$} \\
\hline Catchment size $100 \mathrm{~m}$ & -0.55 & 0.02 & + & 0.13 & 0.09 & & & & - & 0.16 & 0.07 & - & 0.27 & 0.02 \\
\hline Catchment size $300 \mathrm{~m}$ & -0.48 & 0.052 & + & 0.25 & 0.02 & & & & - & 0.14 & 0.08 & - & 0.27 & 0.02 \\
\hline Catchment size $500 \mathrm{~m}$ & -0.45 & 0.07 & + & 0.14 & 0.07 & & & & & & & - & 0.18 & 0.05 \\
\hline \multicolumn{15}{|c|}{$\begin{array}{l}\text { 2-Increase in the number of } \\
\text { culverts }\end{array}$} \\
\hline Catchment size $300 \mathrm{~m}$ & & & - & 0.49 & 0.001 & + & 0.31 & 0.01 & & & & & & \\
\hline Catchment size $500 \mathrm{~m}$ & & & - & 0.48 & 0.001 & + & 0.25 & 0.02 & & & & & & \\
\hline \multicolumn{15}{|c|}{$\begin{array}{l}\text { 3-Increase in the number of } \\
\text { intersections }\end{array}$} \\
\hline Catchment size $100 \mathrm{~m}$ & 0.44 & 0.08 & - & 0.52 & 0.0006 & + & 0.18 & 0.049 & + & 0.18 & 0.06 & + & 0.35 & 0.007 \\
\hline Catchment size $300 \mathrm{~m}$ & 0.51 & 0.04 & - & 0.37 & 0.006 & & & & & & & + & 0.50 & 0.0009 \\
\hline Catchment size $500 \mathrm{~m}$ & 0.47 & 0.06 & - & 0.41 & 0.003 & & & & & & & + & 0.41 & 0.003 \\
\hline
\end{tabular}

